\title{
Short- and long-term outcomes following percutaneous coronary intervention in hepatitis $C$ virus seropositive patients
}

\author{
Ahmed Hussein ${ }^{1 *}$ (D), Mohamed Abdel Ghany ${ }^{2}$ and Hossam Eldin M. Mahmoud ${ }^{3}$
}

\begin{abstract}
Background: Hepatitis C virus (HCV) infection is progressively recognized as a potential atherogenic condition that is associated with coronary artery disease (CAD). Factors that affect the cardiovascular system as diabetes mellitus and dyslipidemia also may affect the outcomes following PCI. So, HCV infection may have an impact on the outcomes following PCl. We aimed to investigate the impact of HCV seropositivity on the outcomes following percutaneous coronary intervention (PCl).

Results: We conducted a multi-center prospective cohort study on 400 patients candidate for elective PCl using drug-eluting stents; 200 patients were HCV seropositive and did not received antiviral treatment, and 200 patients were HCV seronegative. The patients were followed up for 1 year for the development of major adverse cardiovascular events (MACEs) and clinical in-stent restenosis. Multivariate Cox hazard regression analyses for MACEs and clinical in-stent restenosis at 12 months after adjustment for confounding factors showed that HCV seropositivity did not present a higher hazard upon MACEs (adjusted hazard ratio (HR) 0.74; 95\% Cl 0.41-1.32; $p$ value 0.302 ), the individual cardiovascular outcomes (target lesion revascularization (TLR), target vessel revascularization (TVR), myocardial infarction (MI), cerebrovascular stroke (CVS), stent thrombosis, major bleeding, coronary artery bypass graft (CABG), cardiac death, and non-cardiac death), or the incidence of clinical in-stent restenosis (adjusted HR was 1.70; 95\% Cl 0.64-4.51; $p$ value 0.28) compared to seronegative patients.
\end{abstract}

Conclusion: HCV seropositivity had no impact on MACEs, individual cardiovascular outcomes, or clinical in-stent restenosis following PCI for a 1 year follow-up period.

Keywords: HCV seropositivity, PCI, MACEs, Clinical in-stent restenosis

\section{Background}

Many theories suggested infection as a tributary risk factor of CAD [1, 2]; the association between infections and CAD has been explained by different direct and indirect mechanisms [2-4]. The acquired information shows the recognizable proof of viral genomes in the atherosclerotic plaques and furthermore proatherogenic impacts of viral disease in cells applicable to atherogenesis (smooth muscle cells, monocyte

\footnotetext{
*Correspondence: forahmedaly@yahoo.com

'Department of Internal Medicine, Faculty of Medicine, Sohag University, Nasser city, Sohag 82524, Egypt

Full list of author information is available at the end of the article
}

macrophages, T cells, and endothelial cells) [5]. HCV infection is a major public health burden in Egypt; the Demographic Health Survey (DHS) of 2015 showed that among those aged 15-59 years the national seroprevalence was $10 \%$, which is the highest prevalence rate in the world [6]. It was estimated that the global prevalence of $\mathrm{HCV}$ infection is 2-3\% [7]. $\mathrm{HCV}$ infection is progressively recognized as a potential atherogenic condition. Actually, the chronic $\mathrm{HCV}$ disease causes hepatic and systemic inflammation by means of expanded degrees of proatherogenic chemokines and cytokines [8]. Hepatic steatosis is more common in patients with $\mathrm{HCV}$ infection, which has

\section{Springer Open}

( ) The Author(s). 2020 Open Access This article is licensed under a Creative Commons Attribution 4.0 International License, which permits use, sharing, adaptation, distribution and reproduction in any medium or format, as long as you give appropriate credit to the original author(s) and the source, provide a link to the Creative Commons licence, and indicate if changes were made. The images or other third party material in this article are included in the article's Creative Commons licence, unless indicated otherwise in a credit line to the material. If material is not included in the article's Creative Commons licence and your intended use is not permitted by statutory regulation or exceeds the permitted use, you will need to obtain permission directly from the copyright holder. To view a copy of this licence, visit http://creativecommons.org/licenses/by/4.0/. 
many clinical features as those in patients with metabolic syndrome $[9,10]$. Hepatic steatosis is associated with endothelial dysfunction and elevated levels of inflammatory markers [11]. Also, $\mathrm{HCV}$ infection was suggested to be associated with atherosclerosis [3, 12-14], CAD [15-17], carotid artery disease [18], and stroke $[19,20]$. In spite of that, it is still controversial whether there is an association between HCV infection and CAD or not [21-25]. Different studies have shown conflicting results, some studies showed that there is an association between $\mathrm{HCV}$ seropositivity and CAD and carotid atherosclerosis [3, 16, 26, 27], other studies showed that there is no association between HCV infection and CAD, carotid atherosclerosis, or risk of myocardial infarction [2, 28-31], while Pothineni et al. reported that $\mathrm{HCV}$ infected patients had less obstructive $\mathrm{CAD}$ on coronary angiography [32].

We know that the factors have effects on the cardiovascular system as diabetes mellitus and dyslipidemia also affect the outcomes following PCI. It is postulated that infections adversely affect the cardiovascular system. So, HCV infection may have an impact on the outcomes following PCI. Only a limited research has been carried out on this particular topic. Therefore, we conducted this study to investigate the effect of $\mathrm{HCV}$ seropositivity on the short- and long-term outcomes following PCI.

\section{Methods}

\section{Aim of the study}

This study was conducted to detect the effect of HCV seropositivity on the short- and long-term outcomes in patients after PCI.

\section{Design of the study}

This was a multi-center prospective cohort study conducted on 400 patients candidate for elective PCI using drug-eluting stents, at three different University Hospitals, Cath. Lab. Unit from May 2016 to November 2018. The participants were classified into two equal groups: group 1 was seropositive for $\mathrm{HCV}$ and did not received antiviral treatment, and group 2 was seronegative for $\mathrm{HCV}$.

All subjects provided a written informed consent to participate in the study. The study protocol was approved by the ethics committee at Universities where the study was conducted.

Patients who meet the selection criteria were subjected to the following:

1- Identification of cardiovascular risk factors (age, sex, smoking, hypertension, diabetes mellitus, dyslipidemia, body mass index, and family history of CAD).
2- Assessment of symptoms suggestive of coronary insufficiency as typical exertional chest pain and history of admission to coronary care unit with acute coronary syndrome whether unstable angina or MI.

3- Full clinical examination.

4- Resting 12 lead surface electrocardiogram to identify cardiac rhythm and signs of myocardial ischemia (ST segment and T wave abnormalities or pathological Q waves).

5- Echocardiography study was done using a $2.5-\mathrm{MHz}$ transducer and harmonic imaging to measure systolic and end diastolic left ventricular dimensions, segmental wall motion abnormalities at rest, and left ventricle ejection fraction (LVEF) using biplane Simpson's rule.

6- Treadmill stress electrocardiogram testing using Modified Bruce Protocol when indicated.

7- Laboratory testing includes cardiac biomarkers (CK-MB and troponin) measured at baseline and 8-12 $\mathrm{h}$ after the procedure and if indicated during the 12 months follow-up, fasting blood sugar, hemoglobin A1c level, lipogram, HCV antibodies using the third-generation ELISA method [33], liver function, and renal function tests.

8- Coronary angiography was performed by an experienced intervention cardiologist, using Seldinger's technique where a right femoral artery puncture was done then right and left coronary angiogram was performed in multiple projections; coronary stenosis of more than $70 \%$ by visual assessment and documented ischemia was considered for inclusion [34]. The dual antiplatelet regimen consisted of aspirin in loading doses of 300 $\mathrm{mg}$ and maintenance of $100 \mathrm{mg} /$ day maintained indefinitely and clopidogrel loading dose of 300$600 \mathrm{mg}$, followed by $75 \mathrm{mg} /$ day for at least 1 year. After insertion of the arterial sheath to the right femoral artery, patients were administered 10,000 IU or 100-200 IU heparin/kg. PCI was performed using drug-eluting stents by an experienced interventionist who was blinded to clinical and demographic data. After 24-h hospital follow-up, the patient was discharged (if no complication occurred) with prescription of aspirin, clopidogrel, Bblockers, angiotensin-converting enzyme inhibitors or angiotensin receptor blockers, statin therapy, and other medications if indicated as anti-glycemics. Some patients received modified drug regimens due to associated different co-morbid conditions.

The primary end point was MACEs that include TLR, TVR, CABG, MI, CVS, stent thrombosis, major bleeding, and cardiac and non-cardiac death immediately and over 
a period of 12 months. The secondary end point was clinical in-stent restenosis indicated by the recurrence of ischemic chest pain, positive stress electrocardiogram, and new motion wall abnormality by echocardiography. Clinical in-stent restenosis was documented by coronary angiography if not contraindicated. The patients were followed up by clinic visits, at 3 months, 6 months, and 12 months to detect either the primary or secondary end points. Also, telephone communication was available for the patients at any time during the 12 months follow-up. Clinical in-stent restenosis is assessed as a requirement for ischemia-driven repeat revascularization; it was proposed by the Academic Research Consortium, this definition requires both an assessment of luminal narrowing and the patient's clinical context.

The following formula was used to calculate the minimum size of the required sample:

$$
n=(z)^{2} p(1-p) / d^{2}
$$

where $n$ indicates the sample size, $z$ indicates the level of confidence according to the standard normal distribution (for a level of confidence of $95 \%, z=1.96$ ), $p$ indicates the estimated proportion of the population that presents the characteristic (about 10\%), and $d$ indicates the tolerated margin of error (for example, we want to know the real proportion within 5\%).

Using the previous formula for the sample size calculation $(n)=(1.96)^{2} \times 0.10(1-0.10) /(0.05)^{2}=138.3$. So, the minimum sample size is 139 participants.

\section{Participant characteristics}

Patients aged $\geq 18$ years who have symptomatic CAD and showed significant de novo stenotic lesions $(\geq 70 \%)$ of native coronary arteries that were amenable to elective PCI using drug-eluting stents and who agreed and consented to participate in the study were included. We excluded patients who had any of the following criteria: target lesion in the left main coronary artery, patients with chronic total occlusion lesion, patients treated by primary PCI, patients who need bifurcation stenting technique, patients with previous history of CABG, known hypersensitivity to aspirin and clopidogrel, decompensated liver and kidney disease, congenital heart disease, chronic infections other than HCV infection, $\mathrm{HCV}$-infected patients who received antiviral treatment, hematological or oncological disorders, and pregnancy.

\section{Analysis of data}

Data was analyzed using SPSS version 20. Quantitative data were analyzed using the Student $t$ test to compare means of two groups. Qualitative data were compared using Chi square test. Fisher's exact correction was used when the expected cell count is less than 5 . Univariate and multivariate Cox hazard regression analyses for MACEs and clinical in-stent restenosis at 12 months after adjustment for confounding factors were performed. $p$ value was considered significant at or below 0.05 .

The outcome variables were MACEs (TLR, TVR, CABG, MI, CVS, stent thrombosis, major bleeding, cardiac and non-cardiac death) as a primary end point and clinical in-stent restenosis as a secondary end point.

\section{Results}

The study was conducted on 400 patients $\geq 18$ years old who had CAD and are candidate for elective PCI using drug-eluting stents; they were classified into two equal groups: group 1 included HCV seropositive patients who did not received antiviral treatment, and group 2 included HCV seronegative patients.

\section{Baseline socio-demographic and clinical characteristics}

There was a significantly higher number of males in group 1 than group 2 (146 vs $126, p$ value $=0.032)$; also, group 1 had a higher number of smokers than group 2 but was statistically insignificant $(115$ vs $101, p$ value $=$ $0.16)$. There was no significant difference in the mean age of patients in both groups $(51.21 \pm 10.72$ years versus $52.17 \pm 10.39$ years, $p$ value $=0.521)$. Patients in group 2 had a significantly higher mean body mass index than that in group $1(27.64 \pm 3.81$ vs $26.19 \pm 2.9, p$ value $=0.003)$. As regards hypertension, diabetes mellitus, dyslipidemia, and family history of coronary artery disease in both groups, there was no statistically significant difference. As regards the clinical presentation, there was no statistically significant difference between the two groups (Tables 1 and 2).

\section{Baseline laboratory parameters}

The baseline mean of serum low-density lipoprotein (LDL), hemoglobin A1c level, and LVEF in patients in both groups showed no statistically significant difference (Table 3).

\section{Baseline lesion and procedural characteristics}

Patients in group 2 had a statistically significant higher grade TIMI flow on angiography than patients in group 1 . Also, the mean length of stents implanted in group 2 was statistically significantly higher than in group 1, while the number of diseased vessels, mean percentage of luminal narrowing, number of stents implanted, mean stent diameter, and mean dilation pressure showed no statistically significant difference between both groups (Table 4). 
Table 1 Baseline demographics and clinical characteristics

\begin{tabular}{|c|c|c|c|}
\hline Variables & $\begin{array}{l}\text { Group (1) } \\
\text { (HCV seropositive) } \\
\mathbf{N}=200\end{array}$ & $\begin{array}{l}\text { Group (2) } \\
\text { (HCV seronegative) } \\
\mathbf{N}=200\end{array}$ & $\boldsymbol{P}$ value \\
\hline \multicolumn{4}{|l|}{ Age } \\
\hline Mean \pm SD (year) & $51.21 \pm 10.72$ & $52.17 \pm 10.39$ & 0.521 \\
\hline \multicolumn{4}{|l|}{ Sex } \\
\hline Male & $146(73 \%)$ & $126(63 \%)$ & 0.032 \\
\hline Female & $54(27 \%)$ & 74 (37\%) & \\
\hline \multicolumn{4}{|l|}{ Hypertension } \\
\hline Yes & 118 (59\%) & $104(52 \%)$ & 0.159 \\
\hline \multicolumn{4}{|l|}{ Diabetes mellitus } \\
\hline Yes & 108 (54\%) & $108(54 \%)$ & 1.00 \\
\hline \multicolumn{4}{|l|}{ Dyslipidemia } \\
\hline Yes & $103(51.5 \%)$ & $115(57.5 \%)$ & 0.228 \\
\hline \multicolumn{4}{|c|}{ Body mass index, $\mathrm{Kg} / \mathrm{m}^{2}$} \\
\hline Mean \pm SD & $26.19 \pm 2.9$ & $27.64 \pm 3.81$ & 0.003 \\
\hline \multicolumn{4}{|l|}{ Smoking } \\
\hline Yes & $115(57.5 \%)$ & $101(50.5 \%)$ & 0.16 \\
\hline \multicolumn{4}{|c|}{ Family History of CAD } \\
\hline Positive & $5(22.5 \%)$ & $40(20 \%)$ & 0.541 \\
\hline
\end{tabular}

Abbreviations: $C A D$ coronary artery disease, $H C V$ hepatitis $C$ virus, $N$ number, $S D$ standard deviation

\section{Clinical outcomes of 24-h hospital stay follow-up}

The incidence of MACEs was not statistically significantly different between both groups ( $3 \%$ vs $2.5 \%, p=$ 0.76). Also, the individual cardiovascular outcomes (emergency CABG, major bleeding, TLR, TVR, acute stent thrombosis, MI, CVS, cardiac and non-cardiac death) showed no statistically significant difference in both groups (Table 5).

\section{Clinical outcomes at $\mathbf{1 2}$ months follow-up}

The cumulative incidence of MACEs (the primary end point) in patients of group 1 was slightly higher than that in group $2(13.5 \%$ vs $11 \%, p$ value $=0.446)$ but statistically insignificant. Also, the individual cardiovascular outcomes (CABG, major bleeding, TLR, TVR, stent

Table 2 Baseline clinical presentations

\begin{tabular}{llll}
\hline $\begin{array}{l}\text { Variables } \\
\text { Stable Angina }\end{array}$ & Group (1) & Group (2) & $\boldsymbol{P}$ value \\
$\quad \begin{array}{l}\text { Yes } \\
\text { Unstable angina }\end{array}$ & $34(17 \%)$ & $40(20 \%)$ & 0.44 \\
$\quad$ Yes & $112(56 \%)$ & $110(55 \%)$ & 0.841 \\
$\begin{array}{l}\text { NSTEMI } \\
\text { Yes }\end{array}$ & $54(27 \%)$ & $50(25 \%)$ & 0.648 \\
\hline Abbreviations: NSTEMI non-ST elevation myocardial infarction &
\end{tabular}

Abbreviations: NSTEMI non-ST elevation myocardial infarction
Table 3 Baseline laboratory parameters

\begin{tabular}{lccc}
\hline Variables & Group (1) & Group (2) & $\boldsymbol{P}$ value \\
\hline $\begin{array}{l}\text { Serum LDL } \\
\quad \text { Mean } \pm \text { SD }(\mathrm{mg} / \mathrm{dl})\end{array}$ & $135.14 \pm 21.08$ & $135.89 \pm 20.97$ & 0.461 \\
$\begin{array}{l}\text { Hemoglobin A1c } \\
\quad \text { Mean } \pm \text { SD (\%) }\end{array}$ & $7.84 \pm 1.48$ & $7.68 \pm 1.29$ & 0.256 \\
$\begin{array}{l}\text { LVEF } \\
\quad \text { Mean } \pm \text { SD (\%) }\end{array}$ & $50.70 \pm 9.57$ & $49.95 \pm 9.30$ & 0.575 \\
\hline $\begin{array}{l}\text { Abbreviations: } L \text { LD low density lipoprotein, LVEF left ventricle ejection fraction, } \\
\text { SD standard deviation }\end{array}$
\end{tabular}

thrombosis, MI, CVS, cardiac and non-cardiac death) showed no statistically significant difference in both groups. Multivariate Cox hazard regression analyses for MACEs after adjustment of confounding factors (diabetes, hypertension, age, dyslipidemia, smoking, and number of implanted stents) revealed that HCV seropositivity did not present a higher hazard upon MACEs at 12 months follow-up (adjusted HR was $0.74 ; 95 \% \mathrm{CI}$ $0.41-1.32$; $p$ value 0.302 ) (Tables 6 and 7).

The cumulative incidence of clinical in-stent restenosis (all were documented by coronary angiography) (the secondary end point) was not statistically significantly different between both groups at 12 months $(5.5 \%$ vs $5 \%, p$ value $=0.823)$. Multivariate Cox

Table 4 Baseline lesion and procedural characteristics

\begin{tabular}{|c|c|c|c|}
\hline Variables & Group (1) & Group (2) & $P$ value \\
\hline \multicolumn{4}{|c|}{ N. of Diseased Vessels } \\
\hline Single vessel & $106(53 \%)$ & $104(52 \%)$ & 0.678 \\
\hline Two vessels & $53(26.5 \%)$ & $60(30 \%)$ & \\
\hline Three vessels & $41(20.5 \%)$ & $36(18 \%)$ & \\
\hline \multicolumn{4}{|c|}{ Percentage of luminal narrowing } \\
\hline Mean \pm SD (\%) & $84.80 \pm 7.47$ & $83.96 \pm 7.30$ & 0.259 \\
\hline \multicolumn{4}{|l|}{ TIMI flow } \\
\hline Grade 2 & $33(16.5 \%)$ & $16(8 \%)$ & 0.01 \\
\hline Grade 3 & $167(83.5 \%)$ & $184(92 \%)$ & \\
\hline
\end{tabular}

\section{N. of implanted stents}

\begin{tabular}{llll} 
One stent & $84(42 \%)$ & $88(44 \%)$ & 0.9 \\
Two stents & $70(35 \%)$ & $66(33 \%)$ & \\
Three stents & $46(23 \%)$ & $46(23 \%)$ & \\
$\begin{array}{l}\text { Stent Length } \\
\text { Mean } \pm \text { SD (mm) }\end{array}$ & $23.28 \pm 6.72$ & $25.24 \pm 8.98$ & 0.014 \\
$\begin{array}{l}\text { Stent Diameter } \\
\text { Mean } \pm \text { SD (mm) }\end{array}$ & $3.11 \pm 0.46$ & $3.15 \pm 0.40$ & 0.326 \\
$\begin{array}{l}\text { Dilation Pressure } \\
\text { Mean } \pm \text { SD (atm) }\end{array}$ & $13.76 \pm 3.98$ & $13.48 \pm 3.84$ & 0.467 \\
\hline Abbreviations: $N$ number, SD standard deviation & &
\end{tabular}

Abbreviations: $N$ number, $S D$ standard deviation 
Table 5 Clinical outcomes of 24-hour hospital stay follows up

\begin{tabular}{|c|c|c|c|}
\hline Variables & Group (1) & Group (2) & $\boldsymbol{P}$ value \\
\hline \multicolumn{4}{|l|}{ TLR } \\
\hline Yes & $2(1 \%)$ & $1(0.5 \%)$ & 1.00 \\
\hline \multicolumn{4}{|l|}{ TVR } \\
\hline Yes & 0 & 0 & \\
\hline \multicolumn{4}{|c|}{ Emergency CABG } \\
\hline Yes & 0 & 0 & \\
\hline \multicolumn{4}{|l|}{ CVS } \\
\hline Yes & 0 & $1(0.5 \%)$ & 1.00 \\
\hline \multicolumn{4}{|l|}{ MI } \\
\hline Yes & $2(1 \%)$ & $1(0.5 \%)$ & 1.00 \\
\hline \multicolumn{4}{|c|}{ Major bleeding } \\
\hline Yes & 0 & 0 & \\
\hline \multicolumn{4}{|c|}{ Cardiac death } \\
\hline Yes & $2(1 \%)$ & $2(1 \%)$ & 1.00 \\
\hline \multicolumn{4}{|c|}{ Non-Cardiac death } \\
\hline Yes & 0 & 0 & \\
\hline \multicolumn{4}{|l|}{ MACEs } \\
\hline Yes & $6(3 \%)$ & $5(2.5 \%)$ & 0.76 \\
\hline \multicolumn{4}{|c|}{ Acute Stent thrombosis } \\
\hline Yes & $1(0.5 \%)$ & $1(0.5 \%)$ & 1.00 \\
\hline
\end{tabular}

Abbreviations: CABG coronary artery bypass graft, CVS cerebrovascular stroke, MACEs major adverse cardiovascular events, $M I$ myocardial infarction, $T L R$ target lesion revascularization, TVR target vessel revascularization

hazard regression analyses for clinical in-stent restenosis after adjustment of confounding factors (diabetes, age, dyslipidemia, smoking, and family history of CAD) revealed that $\mathrm{HCV}$ seropositivity did not present a higher hazard upon clinical in-stent restenosis at 12 months follow-up (adjusted $\mathrm{HR}$ was 1.70; 95\% CI $0.64-4.51 ; p$ value 0.28 ) (Tables 8 and 9).

\section{Discussion}

It is postulated that infections adversely affect the cardiovascular system and so, it may adversely affect the PCI outcomes. To our knowledge, no previous study was carried out to determine the impact of $\mathrm{HCV}$ infection on the outcomes following PCI. Egypt has a high prevalence of $\mathrm{HCV}$ seropositive patients that may have an adverse impact on the PCI outcomes. Therefore, we conducted this study aimed to define the effect of HCV seropositivity on PCI outcomes, and we found that HCV seropositivity did not present a higher hazard upon MACEs compared to seronegative patients during the 24-h hospital stay and throughout the 12 months followup period. Also, HCV infection did not present a higher hazard upon clinical in-stent restenosis throughout the
Table 6 Cumulative incidence of MACEs at 12 months follow up period

\begin{tabular}{|c|c|c|c|}
\hline Variables & Group (1) & Group (2) & $\boldsymbol{P}$ value \\
\hline \multicolumn{4}{|l|}{ TLR } \\
\hline Yes & $13(6.5 \%)$ & $11(5.5 \%)$ & 0.674 \\
\hline \multicolumn{4}{|l|}{ TVR } \\
\hline Yes & $3(1.5 \%)$ & $3(1.5 \%)$ & 1.00 \\
\hline \multicolumn{4}{|l|}{ CABG } \\
\hline Yes & $1(0.5 \%)$ & $2(1 \%)$ & 1.00 \\
\hline \multicolumn{4}{|l|}{ CVS } \\
\hline Yes & $2(1 \%)$ & $1(0.5 \%)$ & 1.00 \\
\hline \multicolumn{4}{|l|}{ MI } \\
\hline Yes & $5(2.5 \%)$ & $3(1.5 \%)$ & 0.72 \\
\hline \multicolumn{4}{|c|}{ Major bleeding } \\
\hline Yes & 0 & 0 & \\
\hline \multicolumn{4}{|c|}{ Cardiac death } \\
\hline Yes & $3(1.5 \%)$ & $2(1 \%)$ & 0.68 \\
\hline \multicolumn{4}{|c|}{ Non-Cardiac death } \\
\hline Yes & 0 & 0 & \\
\hline \multicolumn{4}{|l|}{ MACEs } \\
\hline Yes & 27 (13.5\%) & $22(11 \%)$ & 0.446 \\
\hline \multicolumn{4}{|c|}{ Stent thrombosis } \\
\hline Yes & $2(1 \%)$ & $2(1 \%)$ & 1.00 \\
\hline
\end{tabular}

Abbreviations: CABG coronary artery bypass graft, CVS cerebrovascular stroke, MACEs major adverse cardiovascular events, MI myocardial infarction, TLR target lesion revascularization, TVR target vessel revascularization

12 months follow-up period compared to seronegative patients.

This study was in line with many previous studies that showed no association between HCV infection and cardiovascular diseases as Völzke et al. who conducted a cross-sectional study of the adult population in the northeast of Germany included $233 \mathrm{HCV}$ Ab-positive patients and 4033 control individuals and showed no independent association between anti-HBs and anti-HCV antibody seropositivity and atherosclerotic endpoints such as prevalent myocardial infarction, stroke, carotid intima-media thickness, carotid plaques and stenos [35]. Also, Momiyama et al. reported in their study that there is a lack of any association between persistent hepatitis $\mathrm{B}$ or $\mathrm{C}$ virus infection and coronary artery disease [28]. Another study conducted by Arcari et al. investigated the association between HCV seropositivity and acute myocardial infarction in a case-control sample of men aged 30-50 years who were on active duty in the US Army during the period of 1991-2000 and found no relationship between $\mathrm{HCV}$ infection and coronary heart disease, but active duty military personnel tend to be in overall good health and have much lower age than the 
Table 7 Multivariate Cox hazard regression analyses for MACEs at 12 months follow up

\begin{tabular}{|c|c|c|c|c|c|c|}
\hline \multirow[t]{2}{*}{ Variable } & \multicolumn{3}{|c|}{$\begin{array}{l}\text { Unadjusted HR ratio ( } 95 \% \text { Cl) for HCV seropositive patients versus } \\
\text { seronegative (reference) }\end{array}$} & \multicolumn{3}{|c|}{$\begin{array}{l}\text { Adjusted HR ratio ( } 95 \% \text { Cl) for HCV seropositive patients versus } \\
\text { seronegative (reference) }\end{array}$} \\
\hline & $\mathrm{HR}$ & $95 \% \mathrm{Cl}$ & $p$ value & $\mathrm{HR}$ & $95 \% \mathrm{Cl}$ & $p$ value \\
\hline MACEs & 0.85 & $0.49-1.50$ & 0.578 & 0.74 & $0.41-1.32$ & 0.302 \\
\hline
\end{tabular}

Abbreviations: $\mathrm{Cl}$ confidence interval, $H C V$ hepatitis $C$ virus, $H R$ hazard ratio, MACEs major adverse cardiovascular events

average age of a patient with acute myocardial infarction. Also, some of the control subjects in their study may have had an asymptomatic CAD [2]. The present study agrees with a study conducted by Kiechl et al. who reported that there is no association between chronic active hepatitis B virus and/or HCV infection and carotid plaque [29]. Also, Forde et al. failed to detect increased ACS risk in HCV-infected patients in their cohort study, but they did not exclude patients who had received antiviral treatment [30], which has been demonstrated to be related to lower cardiovascular hazard [36]. But in our study, we excluded patients on antiviral treatment, and all the participants already had established CAD, and we investigated the effect of HCV seropositivity on the outcomes following PCI which is a different situation to some extent.

On the other hand, many previous studies reported positive association between HCV seropositivity and CAD. Ishizaka et al. showed that there is an independent association between $\mathrm{HCV}$ seropositivity and the presence of carotid artery plaque [3]. Another study conducted by Ishizaka et al. assessed the role of $\mathrm{HCV}$ core protein and carotid atherosclerosis and reported a positive association between $\mathrm{HCV}$ core protein and carotid plaque, but only $1.3 \%$ of the participants tested positive for $\mathrm{HCV}$ core protein [37]. Also, Vassalle et al. showed that $\mathrm{HCV}$ seropositivity was an independent risk factor for coronary artery disease after adjusting for other confounding risk factors [16]. But the association showed in the previous 3 studies $[3,16,37]$ between HCV infection and coronary artery disease was more significant than the associations shown for the well-established risk factors, including male sex, older age, hypertension, dyslipidemia, and smoking. It appears to be impossible that a relationship between $\mathrm{HCV}$ infection and CAD would be more grounded than a relationship with well-established risk factors. Butt et al.

Table 8 Cumulative incidence of clinical in-stent restenosis at 12 months follow up period

\begin{tabular}{lccc}
\hline Variables & Group (1) & Group (2) & $\boldsymbol{P}$ value \\
\hline Clinical in-stent restenosis (documented by coronary & angiography) \\
Yes & $11(5.5 \%)$ & $10(5 \%)$ & 0.823 \\
\hline
\end{tabular}

conducted a large national observational cohort study and reported that $\mathrm{HCV}$-infected persons were younger and had lower lipid levels and a lower prevalence of hypertension, and despite a favorable risk profile, $\mathrm{HCV}$ infection was associated with a higher risk of CAD after adjustment for traditional risk factors, but they did not use adjudicated clinical measures for the diagnosis of CAD and did not consider some important risk factors for CAD as BMI and family history of CAD [15]. Another cohort study conducted by Tsai et al. reported that HCVinfected patients have a higher risk of developing ACS than non-infected patients do [17].

In contrary, Pothineni et al. reported that HCVinfected patients had less obstructive CAD on coronary angiography, but they studied a small number of patients (61 HCV-infected patients and 61 noninfected), and the patients were highly selected on the basis of antigen positivity. They did not consider the degree of $\mathrm{HCV}$-induced liver disease and family history of CAD [32].

\section{Strengths of our study}

First, to our knowledge, no previous study was carried out to determine the impact of $\mathrm{HCV}$ infection on the outcomes following PCI. The second, it was a multicenter study that included a large number of patients.

\section{Limitations of our study}

First, we did not consider some important risk factors that may affect the outcomes as alcohol consumption, physical activity level, socioeconomic status, the patient's lifestyle, complexity and severity of coronary artery lesions, site of coronary lesions, prescribed drug regimens for each patient, and drug adherence; all of which are potential confounding factors. Second, we included all HCV seropositive participants, regardless of the viral load which may play a role. Finally, degree of HCVinduced liver disease was not considered.

\section{Conclusion}

HCV seropositivity had no effect on the cumulative incidence of MACEs, individual cardiovascular outcomes (TLR, TVR, MI, CVS, stent thrombosis, major bleeding, CABG, cardiac or non-cardiac death), or in-stent 
Table 9 Multivariate Cox hazard regression analyses for clinical in-stent restenosis at 12 months follow up

\begin{tabular}{|c|c|c|c|c|c|c|}
\hline \multirow[t]{2}{*}{ Variable } & \multicolumn{3}{|c|}{$\begin{array}{l}\text { Unadjusted HR ratio ( } 95 \% \mathrm{Cl} \text { ) for HCV } \\
\text { seropositive patients versus } \\
\text { seronegative (reference) }\end{array}$} & \multicolumn{3}{|c|}{$\begin{array}{l}\text { Adjusted HR ratio }(95 \% \mathrm{Cl}) \text { for } \mathrm{HCV} \\
\text { seropositive patients versus } \\
\text { seronegative (reference) }\end{array}$} \\
\hline & $\mathrm{HR}$ & $95 \% \mathrm{Cl}$ & $p$ value & $\mathrm{HR}$ & $95 \% \mathrm{Cl}$ & $p$ value \\
\hline Clinical in-stent restenosis (documented by coronary angiography) & 0.96 & $0.41-2.27$ & 0.93 & 1.70 & $0.64-4.51$ & 0.28 \\
\hline
\end{tabular}

Abbreviations: $\mathrm{Cl}$ confidence interval, $\mathrm{HCV}$ hepatitis $\mathrm{C}$ virus, $H R$ hazard ratio

restenosis following PCI at 1 year follow-up period compared to seronegative patients. Therefore, it might be concluded that there was no impact of HCV seropositivity on the cardiovascular outcomes or clinical in-stent restenosis following PCI.

\section{Abbreviations}

CABG: Coronary artery bypass graft; CAD: Coronary artery disease; Cl: Confidence interval; CVS: Cerebrovascular stroke; HCV: Hepatitis C virus; HR: Hazard ratio; LDL: Low-density lipoprotein; MACEs: Major adverse cardiovascular events; MI: Myocardial infarction; PCI: Percutaneous coronary intervention; SD: Standard deviation; TLR: Target lesion revascularization; TVR: Target vessel revascularization

\section{Acknowledgements}

Not applicable.

\section{Authors' contributions}

The corresponding author $\mathrm{AH}$ was a major contributor in writing the manuscript; $\mathrm{AH}$ wrote the methodology, collected and made analysis of data and interpretation of the results, and shared in writing the discussion and the abstract. The author HEM shared in collecting and analyzing data of patients and shared in writing the discussion and the abstract. The author MAG shared in collecting and analyzing data of patients and wrote the background. All the authors read and approved the final manuscript.

\section{Funding}

None.

\section{Availability of data and materials}

The datasets used and/or analyzed during the current study are available from the corresponding author on reasonable request.

\section{Ethics approval and consent to participate}

All subjects provided a written informed consent to participate in the study. The study protocol was approved by:

1. Medical Research Ethics Committee, Sohag Faculty of Medicine, Sohag University. The committee reference number is not applicable. Date of approval, February 2016

2. Ethical Research Committee, Assiut Faculty of Medicine, Assiut University. The committee reference number is not applicable. Date of approval, March 2016

3. Qena Medical Ethics Committee, Qena Faculty of Medicine, South Valley University. The committee reference number is not applicable. Date of approval, March 2016

\section{Consent for publication}

Not applicable.

\section{Competing interests}

The authors declare that they have no competing interests.

\section{Author details}

${ }^{1}$ Department of Internal Medicine, Faculty of Medicine, Sohag University, Nasser city, Sohag 82524, Egypt. ${ }^{2}$ Department of Cardiology, Faculty of Medicine, Assiut University, Assiut city, Assiut 71511, Egypt. ${ }^{3}$ Department of Internal Medicine, Faculty of Medicine, South Valley University, Qena city, Qena 83511, Egypt.
Received: 15 May 2020 Accepted: 9 July 2020

Published online: 25 July 2020

\section{References}

1. Nieto FJ (1998) Infections and atherosclerosis: new clues from an old hypothesis? Am J Epidemiol 148:937-948

2. Arcari CM, Nelson KE, Netski DM et al (2006) No association between hepatitis $C$ virus seropositivity and acute myocardial infarction. Clin Infect Dis 43:e53-e56

3. Ishizaka N, Ishizaka Y, Takahashi E et al (2002) Association between hepatitis C virus seropositivity, carotid-artery plaque, and intima-media thickening. Lancet 359:133-135

4. Oliveira CP, Kappel CR, Siqueira ER et al (2013) Effects of hepatitis C virus on cardiovascular risk in infected patients: a comparative study. Int J Cardiol 164:221-226

5. Shah PK (2001) Link between infection and atherosclerosis: who are the culprits: viruses, bacteria, both, or neither? Circulation 103:5-6

6. Ministry of Health and Population [Egypt], El-Zanaty and Associates [Egypt], ICF International (2015) Egypt Health Issues Survey 2015. Ministry of Health and Population, ICF International, Cairo, Rockville

7. Alter MJ (1995) Epidemiology of hepatitis C in the West. Semin Liver Dis 15: 5-14

8. Zampino R, Marrone A, Restivo L et al (2013) Chronic HCV infection and inflammation: clinical impact on hepatic and extra-hepatic manifestations. World J Hepatol 5:528-540

9. Sanyal AJ, Contos MJ, Sterling RK et al (2003) Nonalcoholic fatty liver disease in patients with hepatitis $C$ is associated with features of the metabolic syndrome. Am J Gastroenterol 98:2064-2071

10. Sanyal AJ (2005) Review article: non-alcoholic fatty liver disease and hepatitis C-risk factors and clinical implications. Aliment Pharmacol Ther 22:48-51

11. Targher G, Bertolini L, Scala L et al (2005) Non-alcoholic hepatic steatosis and its relation to increased plasma biomarkers of inflammation and endothelial dysfunction in non-diabetic men: role of visceral adipose tissue. Diabet Med 22:1354-1358

12. Fukui M, Kitagawa $Y$, Nakamura $N$ et al (2003) Hepatitis $C$ virus and atherosclerosis in patients with type 2 diabetes. JAMA 289:1245-a-6

13. Adinolfi LE, Restivo L, Zampino R et al (2012) Chronic HCV infection is a risk of atherosclerosis. Role of HCV and HCV-related steatosis. Atherosclerosis 221:496-502

14. Targher G, Bertolini L, Padovani R et al (2007) Differences and similarities in early atherosclerosis between patients with non-alcoholic steatohepatitis and chronic hepatitis B and C. J Hepatol 46:1126-1132

15. Butt AA, Xiaoqiang W, Budoff $M$ et al (2009) Hepatitis $C$ virus infection and the risk of coronary disease. Clin Infect Dis 49:225-232

16. Vassalle C, Masini S, Bianchi F et al (2004) Evidence for association between hepatitis C virus seropositivity and coronary artery disease. Heart 90:565-566

17. Tsai MS, Hsu YC, Yu PC et al (2015) Long-term risk of acute coronary syndrome in hepatitis $C$ virus infected patients without antiviral treatment: a cohort study from an endemic area. Int J Cardiol 181:27-29

18. Huang $H$, Kang $R$, Zhao Z (2014) Is hepatitis C associated with atherosclerotic burden? A systematic review and meta-analysis. PLoS One 9: e106376

19. He H, Kang R, Zhao Z (2013) Hepatitis C virus infection and risk of stroke: a systematic review and meta-analysis. PLoS One 8:e81305

20. Adinolfi LE, Restivo L, Guerrera B et al (2013) Chronic HCV infection is a risk factor of ischemic stroke. Atherosclerosis 231:226

21. Wang CC, Kao JH (2010) Hepatitis C virus infection, lipids, and coronary heart disease: a Pandora's box. Hepatology 51:343-344

22. Petta S, Macaluso FS, Craxì A (2014) Cardiovascular diseases and HCV infection: a simple association or more? Gut 63:369-375 
23. Mostafa A, Mohamed MK, Saeed M et al (2010) Hepatitis C infection and clearance: impact on atherosclerosis and cardiometabolic risk factors. Gut 59:1135-1140

24. Wong RJ, Kanwal F, Younossi ZM et al (2014) Hepatitis C virus infection and coronary artery disease risk: a systematic review of the literature. Dig Dis Sci 59:1586-1593

25. Roed T, Lebech AM, Kjaer A et al (2012) Hepatitis C virus infection and risk of coronary artery disease: a systematic review of the literature. Clin Physiol Funct Imaging 32:421-430

26. Ishizaka N, Ishizaka Y, Takahashi E et al (2002) Increased prevalence of carotid atherosclerosis in hepatitis B virus carriers. Circulation 105:1028-1030

27. Pothineni NV, Delongchamp R, Vallurupalli S et al (2014) Impact of hepatitis C seropositivity on the risk of coronary heart disease events. Am J Cardiol 114:1841-1845

28. Momiyama $Y$, Ohmori R, Kato R et al (2005) Lack of any association between persistent hepatitis B or C virus infection and coronary artery disease. Atherosclerosis 181:211-213

29. Kiechl S, Egger G, Mayr M et al (2001) Chronic infections and the risk of carotid atherosclerosis: prospective results from a large population study. Circulation 103:1064-1070

30. Forde KA, Haynes K, Troxel AB et al (2012) Risk of myocardial infarction associated with chronic hepatitis $C$ virus infection: a population-based cohort study. J Viral Hepat 19:271-277

31. Metwally AH, Elgamal MA (2014) The relation between hepatitis $C$ virus and coronary heart disease. Med Hypotheses 82:505

32. Pothineni NV, Rochlani Y, Vallurupalli S et al (2015) Comparison of angiographic burden of coronary artery disease in patients with versus without hepatitis C infection. Am J Cardiol 116:1041-1044

33. Huber KR, Sebesta C, Bauer K (1996) Detection of common hepatitis C virus subtypes with a third-generation enzyme immunoassay. Hepatology. 24 $471-473$

34. Hueb W, Lopes N, Gersh BJ et al (2010) Ten-year follow-up survival of the Medicine, Angioplasty, or Surgery Study (MASS II): a randomized controlled clinical trial of 3 therapeutic strategies for multivessel coronary artery disease. Circulation. 122:949-957

35. Völzke H, Schwahn C, Wolff B et al (2004) Hepatitis B and C virus infection and the risk of atherosclerosis in a general population. Atherosclerosis. 174: 99-103

36. Hsu YC, Lin JT, Ho HJ et al (2014) Antiviral treatment for hepatitis C virus infection is associated with improved renal and cardiovascular outcomes in diabetic patients. Hepatology. 59:1293-1302

37. Ishizaka Y, Ishizaka N, Takahashi E et al (2003) Association between hepatitis $C$ virus core protein and carotid atherosclerosis. Circ J 67:26-30

\section{Publisher's Note}

Springer Nature remains neutral with regard to jurisdictional claims in published maps and institutional affiliations.

\section{Submit your manuscript to a SpringerOpen ${ }^{\circ}$ journal and benefit from:}

- Convenient online submission

- Rigorous peer review

- Open access: articles freely available online

- High visibility within the field

- Retaining the copyright to your article

Submit your next manuscript at $\boldsymbol{\nabla}$ springeropen.com 